\title{
The ILO's Domestic Worker Convention (C189): Challenging the Gendered Disadvantage of Asia's Foreign Domestic Workers?
}

\author{
Stuart Rosewarne, University of Sydney, Australia
}

\begin{abstract}
The International Labour Organization's Domestic Worker Convention, resolved in June 2011 and soon to come into force, is regarded as a watershed in the struggle by a host of civil society groups to get paid domestic work formally recognised, draw such work out of the shadows and secure employment rights and protections for this overwhelmingly female workforce. In covering all paid domestic work, the Convention can also be seen as an important initiative in promoting decent work for migrant workers and especially the many recruited from Southeast Asia and South Asia. However, improvements in employment rights and conditions will likely be frustrated by the inadequacies of the ILO as a global institutional force able to engage member nation states as well as by the entrenched structural inequities in international labour markets marked by barriers based on gender, race and ethnicity, nationality and religion and irregular employment. Progress will depend on the effectiveness of those civil society groups which were instrumental in the negotiation of the Convention to maintain the momentum to break down the barriers and states' reluctance to implement measures that abolish labour market disadvantage.
\end{abstract}

\section{KEYWORDS}

Domestic Worker Convention, globalisation, International Labour Organization, migrant domestic worker

More than six years in the making, the adoption of the Convention on Domestic Work (C189) at the $100^{\text {th }}$ Session of the International Labour Organization's General Conference in June 2011 marks an important moment in the struggles to draw paid domestic work out of the shadows into the mainstream. Because it pertains to all paid employment undertaken in households, the Domestic Work Convention provides a critical springboard for negotiating improvements in working conditions for the large number of women recruited from South East Asia and South Asia as foreign domestic workers. Since its fundamental purpose is to formally recognise this occupation be treated on terms comparable to other forms of paid work, the Convention provides an 
instrument designed to redress the multiple disadvantages faced by the disproportionate number of migrant women workers engaged in paid domestic and care work. The Convention in general and specific clauses designed to meet the particular circumstances and concerns of migrant workers, and a series of supplementary Recommendations, seek to remedy the disadvantage that flows from being employed in an occupation that is generally not regarded as work, the discrimination associated with the female-dominated occupation and shortcomings related to terms of employment and remuneration. A range of other dimensions of the disadvantage experienced by migrant women could also be tackled. These include the discrimination based on race and ethnicity, nationality and religion; the isolated nature of domestic work, which leaves workers subject to a range of abuses and which can frustrate efforts for workers to organise; the restrictions that arise with the limited-term nature of employment for most foreign domestic workers, and; the disadvantage that follows from being separated from family and other origin-country cultural and institutional supports. Insofar as the Convention provides a prescription for the definition of the terms and conditions for all workers who are employed in domestic employment, it provides a particularly important instrument for challenging the vulnerability and labour market disadvantage of foreign domestic workers.

The Convention calls upon member states to provide all employed domestic workers, including migrant workers, with contracts that specify the terms and conditions of employment and remuneration arrangements, to mandate weekly rest days and the right to a safe and healthy working environment, and to establish measures to combat abuse by employment agencies as employers. In advocating that host country governments afford domestic workers conditions no less favourable than those applying to local workers, the Convention reinforces the principles outlined in several other ILO and international Conventions to extend the reach of employment and related human rights to a category of work that generally enjoys few standard protections. ${ }^{1}$

There is, thus, much to be celebrated in the conclusion of the Domestic Workers Convention for the many migrant women engaged in domestic work. The Convention is a significant development because it is a product of the shift in thinking that has become encapsulated in the 'rights-based' discourse. In the ILO's 'decent work' agenda this has focused the concern with employment rights as also requiring an engagement with human rights. When considered as a complement to other key ILO and international conventions, ratification of $\mathrm{C} 189$ and the adoption of relevant regulatory frameworks by labour-export and labour-import states could go some way to redressing the principal manifestations of labour market disadvantage.

My research, based on field work interviews conducted with migrant worker advocacy and other support groups and migrant domestic workers in Hong Kong, the Philippines, Singapore, India and Sri Lanka, and Greece and Italy over the period 2001 to 2012, suggests that there is cause for some caution in investing too much confidence in the Convention as a solution for redressing the disadvantage experienced by foreign domestic workers. My research has been focused on the different organising strategies and struggles that have been waged to establish and strengthen regulations governing labour migration and employment conditions and rights for migrant domestic workers. C189 is one of the institutional products of these struggles, somewhat of an offshoot from campaigns focused on labour-export and labour-import states and the various 
responses of these states. I reflect on these before appraising the efficacy of C189 as an instrument for progressing the rights and employment status of migrant domestic workers.

I contend that there are several reasons for qualifying the achievement of the Convention, and I argue three in particular warrant consideration. The first relates to the limitations of a tripartite negotiation process in which outcomes are contingent upon the agreement being struck by the employer, worker and government representatives who rarely agree on the form let alone the need for employment regulations. The second follows from this and relates to the ILO's lack of purchase as a global institutional force, evident in the lack of traction of ILO Conventions, both with respect to securing member states support in ratifying conventions and in terms of the Organization's limited capacity to monitor and enforce conventions. This is examined in the broader context of the ILO's mandate to endeavour to secure employment rights and protections for workers in the context of global labour markets that are structurally inequitable and which in the nation-state system, and especially that associated with the labour exports states of Southeast Asia and South Asia, inscribe a particular disadvantage for low skilled migrant workers. In a final section I return to reflect on the political force of the civil society groups and unions, the catalysts in moving forward the negotiations on the Domestic Worker Convention, and their capacity to break down resistance to advancing the rights and protections afforded migrant domestic workers.

\section{Contesting Gendered Labour Market Disadvantage}

The drafting of $\mathrm{C} 189$ is the product of a remarkable confluence of forces that places it in a unique position in the history of the labour movement. The struggle to have paid domestic work recognised as an occupation that should be subject to regulation on terms comparable to other waged work has a long history. It figured in debate within the ILO in the immediate post-World War Two, although there was no movement to formally recognise the status of domestic workers employment, and the consequence was that most ILO Conventions explicitly excluded domestic workers from the protections afforded by most employment Conventions. It was not until the new millennium, when the ILO began to engage with the issue of migrant workers, that the particular needs of paid domestic workers were taken up (Demaret 2007).

The employment status of domestic workers became a matter of interest as a result of greater recourse to paid domestic work over the course of the 1970s and 1980s with increasing female labour force participation, particularly in advanced industrial countries, and the changing demographics of familial organisation. Domestic and care work are overwhelmingly female-dominated occupations with next to no regulations governing terms and conditions of employment especially with respect to migrant workers. From the 1980s and more especially into the 1990s, there was a dramatic increase in the employment of migrant women as domestic workers. Recruited from an ever-growing number of countries from the South, race and ethnicity and nationality contributed to the definition of this labour force and labour market disadvantage. But the countries of Southeast Asia and South Asia stand out as major source countries because governments have promoted such labour migration. 
The established organs of the labour movement generally exhibited little interest in addressing the employment position of domestic workers. The impetus for challenging this situation originated mostly from outside the mainstream of the labour movement with a diverse range of social forces emerging to ignite struggles across a number of political domains. ${ }^{2}$ They brought with them a quite unique and dynamic character to the struggle for women's labour rights that helped to underscore the momentum of the struggle. Especially in Europe and the United States, advocacy initially concentrated on endeavours to formally recognise the position of paid domestic workers (Anderson 2000; Hondagneu-Sotelo 2001; Lutz 2008; Schwenken 2005). But, with greater recourse to paid domestic work in an ever-growing number of countries and the ever-increasing number of migrant workers employed as domestic workers, non-government organisations, women's groups and migrant rights advocacy organisations moved to draw attention to conditions of employment and work-related abuses and to lobby for employment protections. An intriguing confluence of forces was set in train to generate a dramatic re-orientation in how labour movement practices and strategies were pursued.

This was especially the case across Southeast Asia. Non-government and civil rights organisations and faith-based groups worked, and continue to do so, alongside migrant worker advocacy groups to promote the rights of workers. In the Philippines, one of the largest source countries for domestic workers, campaigning was initially concentrated on the position of Filipina workers, based on advocacy work that was taken up in host - or labour-import - countries and in campaigns within the Philippines that focused on lobbying for more government protection.

With a considerable diversity of destinations, the growing global reliance upon foreign domestic work also added another unique dimension, a cross-border or transnational and even internationalist orientation, to advocacy and organising endeavours. This was particularly the case among the organisations and groupings involving Filipina workers, especially in several European states and parts of Southeast Asia. These cross-border alliances and associations were founded on an internationalism that was considerably more tangible than was evident in the mainstream labour movement. ${ }^{3}$ This sometimes took the form of transnational networks, such as Kalayaan, or more consciously internationalist movements, most notably Migrante International. There were also less formally constituted associations, often organised on the basis of personal transnational networks, such as those pursued through religious institutions. ${ }^{4}$ They linked with others to consolidate transnational lobbying efforts. For example, Kalayaan in Europe joined with the European migrant domestic worker network, RESPECT, and SOLIDAR, the Brussels-based labour movement NGO, and pressed unions to support employment rights for migrant domestic workers. They also lobbied European parliamentarians and the European Commission resulting in the European Parliament conducting a public hearing on 'Regulating Domestic Help in the Informal Sector' in 2000.

In Southeast Asia, there was an inherently transnational character to advocacy and campaign work, based initially on the national origin of migrant workers, and this has been underscored by initiatives to assist other migrant women workers to form their own associations. The Asian Migrant Centre, the Hong Kong-based advocacy and 
research centre, drew on the model of the well-organised Filipina workers' union to support the formation of an Indonesian migrant workers union.

These efforts were a precursor to the more ambitious objective of bringing together migrant domestic workers from all origins to form the Asian Domestic Workers Union in Hong Kong in 1989. This particular coalition was not without its tensions, mostly because it was dominated by Filipina members much to the chagrin of other nationalities, and the Union did not survive these. The Coalition of Domestic Workers Unions, a new grouping, was formed in 1998 and, more inclusive, has proved more enduring (Swider 2006). The European network for migrant domestic workers, RESPECT, has been a force to reckon with, as has the more globally-focused Women in Informal Employment: Globalizing and Organizing (WIEGO) in more recent times.

These transnational and internationalist tendencies were consolidated with the formation of regional advocacy forums and networks. Reflecting the numerical significance of women from Southeast Asia recruited into the global labour market, Asia became a notable crucible for these. The Asian Domestic Workers Network was formed in 2005 following the Asian Domestic Workers forum held in Hong Kong in 2004. The Network was organised by the Committee for Asian Women (CAW) and the lobby groups United for Foreign Domestic Workers Rights, the Asia Pacific Forum on Women, Law and Development and CARAM Asia. Aspirations to cement a truly global transnational alliance came together with the formation of the International Domestic Workers Network.

The advocacy of rights for migrant domestic workers was a natural corollary of the burgeoning women's movements across the region, and, as a focal point of concern, the cross-border exchanges strengthened the momentum in the development of transnational advocacy of worker rights as a gender-based concern. The force of this was reinforced by feminist activists and researchers becoming engaged in the cause of migrant domestic workers. One result of this engagement was that the significance of this paid domestic work undertaken by migrants became the subject of a remarkably extensive body of research. ${ }^{5}$ In documenting the undervaluing of paid domestic work and the precarious and vulnerable position of migrant workers, this research made the case for regulating employment conditions and for setting standards.

The scale of this research endeavour can be attributed to a number of factors. The active participation, indeed encouragement, of migrant worker advocates and workers themselves to document and publicise the significance of domestic work was crucial. The readiness of Filipina workers, in particular, to be the subjects of research was somewhat strategic, motivated by the desire to engage more voices to advance their cause. ${ }^{6}$ The extent of the research output also reflected the growing traction of feminist critique, while the analysis of domestic work proved a fertile ground for exploring different research methodologies and tendencies within feminist discourse. Moreover, the activist bent of this research agenda, with researchers involved in organising and lobbying campaigns, underscored the research drive. Needless to say, the migrant domestic worker research agenda helped to position the situation of migrant domestic workers within international policy debate. It both informed and impelled the research and policy preoccupations of those international agencies that had a specific mandate to advance the position of women, and most notably UN Women, formerly UNIFEM, and the ILO.? 
The International Organisation for Migration, which has been resistant to supporting efforts to regulate recruitment and employment conditions, felt obliged to enter the debate to protect the rights of migrant workers, although it has generally approached the issue of women's employment rights as a trafficking management concern.

These various efforts strengthened the voice of migrant women workers and had a catalytic effect in stimulating increasing dialogue within peak union councils and the international labour movement over the course of the 1990s and into the 2000s. The support of the trade union movement, and especially the IUF ${ }^{8}$ and the European Trade Union Confederation, proved crucial in building on the European Parliament's engagement with domestic worker rights. The ETUC 2005 conference Out of the Shadow: Organising Domestic Workers. Towards A Protective Regulatory Framework for Domestic Work, organised in conjunction with the International Restructuring Education Network Europe (IRENE) and the Platform for International Cooperation on Undocumented Migrants (PICUM), underscored the momentum of the campaign for introducing measures to regulate domestic work (Mather 2005). The Convention was also a natural corollary of the ILO's Decent Work for Migrant Workers agenda. But it must also be seen as the product of campaigns that were pursued across a range of institutional and political contexts. The governments of labour-export countries and labour-import countries have been subjected to the unrelenting lobbying of these groups. In those instances where civil society groups have little or no political traction, and most obviously in the Gulf states, the exercise of some political leverage to influence labour migration policy and employment practices has quite often been taken up by UN Women (formerly UNIFEM) and/or the ILO.

\section{Labour-export States' Policy Responses to Protect Migrant Workers}

Labour migration has been a key component of economic policy for most governments across Southeast Asia and South Asia. Migrant workers earnings have become one of the largest sources of foreign exchange earnings for many economies in the region. With women making up a numerically significant proportion of these workers - over half of the Philippines' workers and a disproportionately greater number of Sri Lanka's and Indonesia's migrant workforces - and the great majority working as foreign domestic workers, the earnings from working in the hidden occupation women workers account for a large share of remittance flows to these countries.

The development of labour export programs were largely the product of government initiatives. Most have set up some form of framework to facilitate recruitment and oversee the migration process, but throughout Southeast Asia and South Asia these functions have been assumed by private agencies that now manage the recruitment and training, assistance in securing funds to meet the costs of migration, and the overseas placement of workers. Notwithstanding the privatisation of the labour trade, governments, needless to say, retain vested interest in maintaining the flow of migrant women workers, and governments have come under intense political pressure to adopt measures to ameliorate the abuse of migrant domestic workers that continues to plague the industry. Initial responses, the evidence suggests, were somewhat desultory or, at least, proved to be so. However, over time, and partly in response to concerns about the 
loss of national prestige, more concerted efforts to regulate employment terms and conditions have been pursued. For instance, the Philippines and Indonesia in particular, and Sri Lanka to a lesser extent, mandated requirements that prospective workers complete pre-departure programs to better acquaint workers with the work demands that would be required of them as well as with their employment rights. Several governments have appointed labour attachés or designated officers in embassy and consular offices to represent the interests of migrant workers, and a number of 'safe houses' have been established providing sanctuary for women workers fleeing abusive employers (Baruah and Chettri 2012; CARAM 2011). ${ }^{9}$ The Philippines and Indonesia governments have designed employment contracts that stipulate minimum remuneration and employment conditions that must be signed before exit visas can be issued. From time to time, individual governments have banned agencies that do not comply with transparent recruitment procedures or that fail to protect foreign domestic workers from abuses. ${ }^{10}$

Over the years there have been a number of attempts to restrict the recruitment of women for foreign domestic work. The governments of the Philippines, Indonesia and Sri Lanka have banned recruitment for employment in countries in the Gulf states and Southeast Asia. Other South Asia governments have been more determined to restrict or prohibit women's migration, partly in response to reported abuses and, in the case of Nepal, the realisation that it did not have the resources to manage women's migration, but also on religious and patriarchal grounds in the instances of Bangladesh and Pakistan (Afsar 2005; Raghuram 2005). In 1999 the Indian government banned the deployment of women for domestic work in Kuwait because of the record of abuses. In 2002 it introduced a minimum age requirement for women engaged as foreign domestic workers, of 30 years, and mandated a \$US2500 security deposit to be paid by employers as an exit visa requirement, and this largely extinguished documented migration (Rajan, Varghese and Kumar 2011).

However, rather than stop the migration of women, such restrictions appear to generated irregular labour flows or undocumented migration. Unauthorised cross-border movement is significant, and more especially among some of those worker cohorts who are among the lowest paid, such as those from Nepal and Bangladesh (Sarker 2012). ${ }^{11}$ Governments have had little success in stemming undocumented migration, and the bureaucratic requirements and systemic corruption in the migration bureaucracies of the Philippines, India and Indonesia, aided by corrupt or unlicensed recruitment agents and supportive counterparts in destination countries, only serves to add to the scale of the irregular flow of women workers (Sim and Wee 2009; Rajan, Varghese and Kumar 2011; Sihaloho 2012; Tan 2012). Employing undocumented workers can be to the employer's advantage - the great majority of Malaysian employers apparently preferring to employ 'illegal or "express" foreign maids because they are cheaper than through [recruited through] proper channels' (Looi, Goha and Raman 2009). Moreover, there is a strong impetus for workers to seek overseas employment through irregular channels because of the time-consuming and expensive nature of authorised employment processes. And the nature of most migrant women's work, conducted in the private realm of the employer's residence provides a haven for the undocumented migrant - as well as a space largely sheltered from what protective measures exist (Moors and de Regt 2008). Nor is irregular migration and employment a peculiarly Asian phenomenon; it is global and as such 
draws Asia's migrant women workers onto the global stage (Corpuz 2011; de Regt 2010; Raijman, Schamman-Gasser and Kemp 2003; Young 2001). The contemptuous attitude of the governments of some destination countries to the efforts by labour-export countries to stem irregular movement, such as Malaysia and Saudi Arabia, only serves to help institutionalise undocumented migration (Nie 2012; cawinfo 2012). ${ }^{12}$

This is not to argue that there has not been any progress in labour-export states' attempts to regulate employment and labour migration standards. On the contrary, governments have successfully negotiated Memorandums of Understanding with a number of Gulf states to formalise standards, although some of these do tend to be somewhat opaque and the promises of protection afforded by such agreements does not necessarily translate into concrete measures. ${ }^{13}$ The UAE introduced a written unified contract for domestic workers that stipulates the duration of contract, salary and other benefits, accommodation, healthcare, working hours, paid leave, repatriation ticket, disputes settlement, recruitment fees, and coordination with concerned embassies. Subsequently, a 24-hour hotline and complaint website was set up for migrant workers, and stiff penalties were gazetted for anyone facilitating the employment of undocumented workers (Migrant Forum in Asia 2010). Domestic workers, however, remain expressly excluded from the protection of labour law. Some Gulf and Middle East states are considering amending the kafala system, which indents migrant workers to a private sponsor. This follows concerted efforts by the ILO, and Bahrain has announced it will replace the system of sponsoring migrant workers with a state authority. Other Gulf states are now also reflecting on changing the system, although others continue to resist making any changes (Kahn and Harrof-Tavel 2011). ${ }^{14}$

The object of much criticism from migrant worker activists, the Singaporean government has been endeavouring to improve that country's image as an employer of foreign domestic workers and has pursued a range of measures to stop the abuse of domestic workers. The government has resolved to introduce legislation similar to Hong Kong and Taiwan that would afford foreign domestic workers a day off. This would take effect from 1 January 2013, but would only apply to new recruits, and the legislation mirrors that of Taiwan insofar as it allows employers and workers to negotiate away the day of rest, which is a concern because in Taiwan only around 5 percent of migrant domestic workers actually have a regular day off (Lok-Sin 2011). In promising to adopt measures to afford some protection for workers, even some recruitment agencies are responding to criticisms and the threat that governments will restrict women's overseas employment if they do not improve their practices and oversight of employment conditions.

There are, then, some positive developments, and the passage of the Domestic Worker Convention must be regarded as a factor in this. However, it is evident that efforts to progress migrant domestic worker rights through bilateral agreements will have limited traction given the ability of labour-import economies to source labour needs from an ever-growing number of countries. The desire to contain the costs of labour and to meet increasing demand for domestic workers has prompted labour-import countries, such as Malaysia, Saudi Arabia and Singapore to expand the number of countries from which domestic workers are recruited (Migrant Rights International 2012; Nee 2011). ${ }^{15}$ 
The global nature of the challenge is exacerbated by the pressure on governments in the South to follow the prompting of the World Bank to establish labour-export programs as an export revenue earning strategy. The consequences of this are neatly illustrated across Asia, and especially by the case of Nepal which thought it had secured a niche in negotiating a labour migration accord with Malaysia following the Bangladeshi government's decision to ban the migration of women workers to Malaysia. The accord would have resulted in Nepalese workers becoming among the lowest paid and most poorly treated migrant workers, but the arrangement evaporated when Bangladesh announced its intention to lift the ban (Klep 2011; Loh 2011; Smith-Gary 2011). ${ }^{16}$ Competition between states to secure employment opportunities presents a systemic obstacle to efforts to negotiate conditions and remuneration standards for domestic workers. This is obviously compounded by the extent of recourse to undocumented workers, and highlights the paramount need for global agreement on employment standards.

\section{The Institutional Weakness of the ILO Tripartite Framework}

The negotiation of the ILO Convention on Domestic Work does mark an important step in the endeavour to recognise domestic workers in the mainstream of the labour force. The tripartite ILO framework that brought representatives of employers, workers and governments coming together, and thus signalling the preparedness to negotiate an accord that would afford some protection and minimum standards for domestic workers, provided a potential means for overcoming some of the hurdles that have marred efforts by labour-export states and migrant advocacy groups to progress agreements on employment conditions with individual labour-import countries. Moreover, the momentum of the deliberations of the Committee drafting the Convention on Domestic Work s was bolstered with the participation of several advocacy groups, in a notable shift in practice, and Worker representatives included domestic workers in their delegations (ILO 2011c). ${ }^{17}$

However, there were marked differences over the form the ILO instrument should take and the extent to which it should specify standards. Employer and some government representatives preferred formulating a Recommendation, rather than a Convention, that would guide standards and regulation setting (ILC 2010). Pressured into conceding that a Convention would be concluded, they then stressed the importance of designing an instrument that provided flexibility and diversity, that would not be too prescriptive and which should accommodate national circumstances, and these sentiments were reflected in the final draft (ILO 2011b; ILO 2011c). ${ }^{18}$ The Recommendations, negotiated as a supplement to $\mathrm{C} 189$, do provide greater definition of employment rights and entitlements as well as member state obligations, although even these retain the inclination to provide for flexibility in the regulation of domestic work.

The Convention might well have launched a springboard for bringing domestic work into the mainstream, although it does so in an extremely tentative way, and this is all the more so with respect to institutionalising the rights of migrant domestic workers. In large measure this is simply the consequence of the difficulties of negotiating an accord that sought to break new ground in context of the tripartite ILO process. But the 
shortcomings of $\mathrm{C} 189$ are more deeply rooted than this because they are reflective of fundamental limitations of the ILO's organisational charter and how the ILO has endeavoured to respond to these limitations.

The tripartite framework certainly impedes progress on negotiating of employment conventions, but unlike other international economic institutions the ILO's resolutions do not have the same legal force or political purchase as those that are concluded by, for instance and most obviously the IMF, the World Bank and the World Trade Organization. The negotiation of resolutions within the ILO framework traverses a more difficult passage than occurs within these other institutions, and there is no obligation on or compulsion for member states to ratify ILO Conventions. Even when adopted there are limited effective mechanisms for sanctioning states that do not adhere to a Convention's obligations, and the ILO has limited resources that impair its capacity to monitor, police, let alone enforce member state commitments to Conventions (Alston 2004). Notwithstanding a convention coming into force, the standards set out in ILO Conventions only apply in those countries which ratify the relevant convention. The ILO simply does not have the leverage that other international economic institutions are able to exercise.

The record on Convention ratifications highlights the real weakness in the ILO's standing, and this is most apparent with respect to Conventions pertaining to labour migration. The Philippines is the only member state that promotes labour migration to have ratified the Migration for Employment Convention, 1949 (C97) and Migrant Workers (Supplementary Provisions) Convention, 1975 (143), although Indonesia has indicated an intention to ratify C97, while not one major destination country that recruits workers from Southeast Asia or South Asia has ratified either C97 or C143. ${ }^{19}$ Furthermore, although C189 implores member states to protect migrant domestic workers against abusive practices by private employment agencies, not one of the major labour-export states of Southeast Asia or South Asia, or labour-import states for that matter, has ratified the Private Employment Agencies Convention, 1997 (C181).

\section{The Reorientation of the ILO Project: From Standards to Principles?}

The ILO has been very cognizant of this weakness in its constitution, and has responded by concentrating its organisational energies on trying to engage member states to embrace non-binding principles, and towards this end has lobbied and assisted members to develop measures to regulate employment. A noteworthy illustration of this strategy was the formulation of the Multilateral Framework on Labour Migration: Nonbinding Principles and Guidelines for a Rights-based Approach to Labour Migration concluded in 2006. Even though the Multilateral Framework has no legal force, very few member states have engaged with it.

In many respects the shift from the concern with designing, negotiating and promoting employment standards to that of promoting non-binding principles simply reflects the extent to which the organisational force of the ILO has been overshadowed by the neoliberal agendas pushed by the World Bank, the IMF and the WTO. Confronted by the dynamics of globalisation, and especially the liberalisation of international trade in goods and services, of investment and financial flows, as well as the increased significance 
of international labour mobility, the Organization felt compelled to explore how to recuperate its relevance as an institution involved in shaping employment relations. Given the associated turn among member states away from strengthening employment relations regulation, there may have been little option to move away from formulating, and trying to win support for, a broad range of employment standards that prescribed rights and protections. Developing an agenda that was not openly at odds with the resistance to this largely explains the ILO's decision to adopt the vaguer notion of 'decent work' to spearhead the reorientation (Alston 2004; Standing 2008).

As this reorientation in focus has translated into the migrant worker rights-based agenda, the more it reads like the abandonment of endeavours to establish global standards. The 'rights-based approach' to international migration concedes the right of sovereign states to develop their own policies to manage labour migration (ILO 2010: 253). The approach does make the case for the ILO assisting states in this enterprise, guided by the principles of relevant ILO Conventions. But the emphasis is on guidance and not adherence to principles. Rather than progressing employment regulations and standards within the Convention framework, the endeavour is premised on promoting the rights-based approach outside the ILO's formal organisational reach. More emphasis is placed on member states engaging with social partners and collaborating with one another on inter-state collaboration and governments working in partnership with migrant worker advocacy groups, although, as noted, this has not proved particularly effective in progressing the rights of migrant domestic workers.

\section{Conceding the Bounds of Segmented International Labour Markets?}

C189 recognises the significant contribution of domestic workers to the global economy and the potential for the continued growth of the migrant domestic labour force. By implication $\mathrm{C} 189$ endorses the prospect of this and does so subject to promoting measures that would provide for the effective protection of the human rights of migrant workers and to meeting the ILO's objective of 'decent work' based on an 'orderly and equitable process of labour migration' (ILO 2010: 263). However, it is questionable whether the reach of the Convention is sufficient to combat the structural inequities in the international domestic worker labour market. Several critical shortcomings are evident.

C189 is a significant development insofar as it expressly acknowledges that many of the predominantly women who are employed in domestic work, including the many migrant women, 'are particularly vulnerable to discrimination in respect of conditions of employment and work, and to other abuses of human rights,' and that 'discrimination in respect of employment and occupation,' should be eliminated and that 'remuneration is established without discrimination based on sex' (Article 3, Article 11). Yet this is an occupation that is overwhelmingly defined in terms of gender and unlikely to change. Employment 'based on sex' is an essential aspect of the job as it has been constructed. Moreover, it is not just the gender/sex attribute that frames the definition of domestic work in its global context. Race and ethnicity, nationality and religion are also critical in the making of the migrant domestic worker. A combination of attributes positions these workers in the lower rungs of a highly segmented global labour market. One other 
obvious manifestation of this is the extent to which there is a hierarchy with remuneration rates and conditions of employment that varies according to race, ethnicity and religious orientation and national origin irrespective of the levels of experience (ILO 2010). ${ }^{20}$ The labour market hierarchy is even evident in host states that have legislated minimum conditions for all foreign domestic workers irrespective of origin, such as in Hong Kong and Taiwan where employment regulations do not prevent some worker cohorts from being employed on inferior terms to their counterparts. C189 does not contest this, and indeed it may be argued contributes to institutionalising the hierarchy of the global labour force.

The layering of this global division of labour has been deepened with ever-new sources of labour as economic malaise in the global South drives women to seek work overseas. In the more recent instances of states across Southeast Asia and South Asia supporting labour migration to boost export revenue, the women recruited from these economies enter the global workforce at the bottom of the ladder, are paid lower wages and are subject to more exploitative employment conditions than, say, Filipina workers. It was precisely this situation that frustrated the Nepalese government when negotiating the employment of Nepali women to Malaysia. The problem is systemic insofar as international competition for labour market share in the World Bank scenario diminishes the ability of labour-export states, migrant worker groups and the ILO to establish minimum terms and conditions of employment for the global worker. And all efforts to establish internationally-agreed labour codes of conduct and standards outside the ILO have also failed (Alston 2004; Taylor 2011).

Another structural feature of this global labour market is the lack of labour market freedom that the Convention does not really counter. This is evident in the near universal practice of resident and work visas for employment in low-skilled occupations, including domestic work, being issued on the condition that migrants have a contract to work for a particular employer. The ability of migrants to exercise any choice in selecting an employer to work for is quite restricted when employment is organised through agencies. This lack of market freedom is exacerbated by the very limited right of workers to terminate contracts with an employer and negotiate alternative employment without forfeiting the residence and work visa placing workers in an extremely poor bargaining position. C189 (Article 9) points to measures to support the freedom to contract, but this would not prevent the limited contractual rights. The vulnerable contractual position of workers is evident in the potential for the terms and conditions of mutually-agreed employment contracts to be unilaterally varied by a placement agency or an employer upon the worker's arrival at the place of employment, and C189 (Articles 7, 8 and 15) afford some protection from this abuse, although it is doubtful that these clauses will be fully acted upon when not one of the governments of the major foreign domestic labourexport or labour-import countries has ratified the Private Employment Agencies Convention (C181) which is designed to regulate the recruitment industry. C189 does not address the problem of bonded labour, a not uncommon phenomenon that arises because workers have to borrow funds to meet the cost of their recruitment and placement. While Article 9 proscribes the confiscation of workers' travel and identity documents, the Convention does not contest the practice of what is, in effect, an indenture, and this institutionalises labour market disadvantage. The ILO is well aware of 
the potentially abusive consequences of this arrangement, and especially the kafala system as noted, but the practice of tied employment appears well entrenched and unlikely to be abandoned in any of the major labour-import economies.

The disadvantage of tied-employment is compounded by the fact that migrant domestic workers are employed overwhelmingly on limited-term contracts. The duration of contracts is generally restricted to two to three years, varying from one country to another, and workers are usually required to return to their country of origin before renewing or striking a contract with a different employer, and this makes for a precarious existence. During the course of my research I met women who had been in continuous employment on successive contracts in Hong Kong for many years, living most of their lives in Hong Kong, but are denied the range of civil and political rights that go with permanent residence or citizenship. Interestingly, some migrant workers have recently tested the right of the administration to refuse those with an extended residence history from applying for permanent residence. Several long-term resident Filipina domestic workers challenged the 'right of abode' law in the courts and applied for permanent residence. In September 2011 Hong Kong's First Court of Instance (FCI) determined that legislation restricting foreign domestic workers from qualifying for permanent residence contravened the Hong Kong Basic Law. The glimmer of hope that this institutional obstacle could be dismantled was extinguished when the government successfully appealed this determination (Asia Pacific Mission for Migrants 2011). ${ }^{21}$

The overturning of the FCI's ruling was based on the state's right to exercise immigration controls. The Court of Appeal's 'Mr Justice Andrew Cheung Kui-nung wrote in the judgement: "It is a fundamental principle of international law that a sovereign state has the power to admit, exclude and expel aliens. The difference of treatment flows inevitably from the fact of the political boundaries which are drawn across the globe" (Chiu and Lau 2012). Rather than fitting the criterion of 'ordinarily resident', which was the basis of the worker's application, the Court of Appeal determined that these foreign domestic workers' residence was not 'ordinary' but 'very special', and that the legislature had the authority to define or change the meaning of 'ordinarily resident'. ${ }^{22}$

The Domestic Worker Convention does nothing to contest the restriction on residency, and given its place in the international political system based on regard for national sovereignty there was obviously very little possibility that negotiations would ever challenge the right of labour-import states to regulate who can and cannot be issued with visas and the terms of those visas. The absence of any direction on residence rights within the Convention accommodates the concerns of labour-import nations that this particular workforce cohort should not be granted permanent resident rights. There is nothing in C189 that affords the worker any protection from the vulnerability of temporariness, and Article 8 (4) in effect sanctions temporariness by speaking to the entitlement for repatriation upon the expiry of an employment contract.

A further aspect of the international labour market that has been highlighted here is the vulnerable and subordinate position of domestic workers who are undocumented. C189 explicitly refers to affording measures to improve the position of undocumented workers or, as the ILO describes such workers 'migrant workers in irregular status' (ILO 2010: 31). Interestingly, this analysis of irregular migration is little more than descriptive 
and provides no real direction for how this phenomenon should be addressed beyond framing responses in terms of managing trafficking and smuggling. In some respects, this lacuna reflects the inability to get around the resistance to achieving any support from employer groups, member states and even worker representatives for establishing measures to regularise and afford some protections for undocumented workers. Undocumented or irregular migration has become a significant feature of the international labour market for domestic work, reinforcing the extent to which it is organised in the shadows of the economy, and underscoring the subordinate and vulnerable position of migrant domestic workers. While C189's silence on the subject means that undocumented workers are not excluded from the protections afforded domestic workers in general, the silence means that any positive steps are wholly contingent upon the volition of host states.

Of course, the ILO is not the cause of the labour market structure that locks migrant domestic workers into subordinate and precarious positions in the global economy. Perhaps, as some critics have argued, in the interests of getting agreement on advancing some rights for migrant workers and not foreclosing employment opportunities it is necessary to concede forsaking some rights (Bell and Piper 2005; Ruhs and Martin 2008). This echoes the World Bank's contention that measures to strengthen labour market regulations would impede the free movement of labour and restrict the economic opportunities for overseas employment (World Bank 2006). The problem here is that the negotiations are premised on trying to strike a balance between employment rights and less favourable terms and conditions that make attractive the employment of migrant domestic workers, and this has resulted in the making of a Convention that is both weak and which reflects and institutionalises the systemic labour market inequities.

There is one further critical aspect of this process worthy of consideration. The Convention is primarily concerned with securing the global labour market for migrant domestic workers and affording greater protection for these workers. This is to be applauded, but in the process the focus is concentrated on setting some minimum employment standards, promoting decent work for wage labour, while the broader project of enhancing these workers' human rights tends to be marginalised. Many of the worker rights that are advocated in other conventions and which implant human rights, including the UN Convention on the Protection of all Migrant Workers and Members of Their Families, are effectively abandoned. This is evident in the absence of any measures in C189 that would afford family or civil rights and in the concessions that sanction restrictions on mobility.

\section{Beyond the ILO and the Struggle for Migrant Domestic Worker Rights?}

I do not want to dismiss C189 out of hand. It is an important institutional development in its own right insofar as it acknowledges the feminisation of international labour migration and, with this, the marked growth in the employment of foreign domestic workers. C189 marks a critical stage in the endeavour to both recognise what is distinct about, and the need to regulate, paid domestic work. In outlining some minimum desired conditions and standards of employment and linking these to recognising employment rights for domestic workers, the $\mathrm{C} 189$ brings in from the cold a 
category of work that hitherto has been excluded from the protection afforded by almost all other ILO work and migrant-worker related Conventions.

It is folly to assume that ILO officials and those interest groups that campaigned for the Convention were not cognizant of the limitations of the ILO and more particularly the Conventions. For example, at first sight there does not seem to be any logic in negotiating a clause such as Article 15 that would protect migrant workers from abuse by employment agencies when no labour-export or labour-import country has ratified $\mathrm{C} 181$. Yet, such a clause does provide the possibility for those lobbying and pressing governments to adopt regulations to establish employment rights and protections to exercise some leverage. More generally, C189 makes more concrete a platform for the advocacy of migrant domestic worker rights; it engenders the possibility for injecting more momentum into the struggles to enhance worker protection and rights. Some heart can be taken from the tenor of the debate on the wording of the Convention because member states within the International Labour Conference were generally quite supportive. There are at least a dozen countries that have already ratified moving to ratify the Convention, ${ }^{23}$ while there are a number of governments that already have in place regulations governing waged domestic work.

There is, in fact, something in this possibility of C189 being a springboard for building on the campaign for migrant domestic worker rights especially when it comes into force in 2013. Migrant worker organisations, civil society groups, trade unions and international organisations have embarked on a concerted campaign to press governments in both host and origin countries to adopt the Convention (IDWN 2012; SOLIDAR 2012). There have been innumerable celebrations organised which have sought to consolidate the momentum of the struggle, including those on International Migrants Day in December 2011 and International Women's Day actions in March 2012 that were held throughout the world. The organised labour movement has embraced with unparalleled determination the cause to have the Convention ratified. The International Trade Union Confederation joined by several partners - including the IDWN, the IUF, the European Trade Union Confederation and SOLIDAR - have launched the ' 12 by 12 ' campaign that has focused on winning the support of twelve governments to be among the first to ratify the Convention in 2012. This is an extraordinarily determined campaign that could have some traction.

However, the promise of this needs to be tempered by the evidence that the goodwill displayed by member states in the drafting deliberations will not necessarily translate into concrete policies. There have been some positive outcomes, although these have occurred outside the C189 framework, as noted. It is also evident that, notwithstanding public endorsements of $\mathrm{C} 189$, many member states are unlikely to ratify the Convention; progress in extending domestic worker protections and rights will necessarily depend on the political purchase of the campaign being spearheaded by the ITUC. And it is possible that this was anticipated by the ILO. C189 supplementary Recommendations (Recommendation 23) exhort the member states involved in the promotion of workers for overseas employment and recruit foreign domestic workers labour to negotiate bilateral, regional or multilateral agreements to underwrite the regulation of decent work provisions for foreign domestic workers. 


\section{Conclusion}

The structural pressures that have driven the turn to labour migration place migrant workers in a vulnerable position in the global labour market. This vulnerability is compounded in the instance of women employed in domestic work because of its nature. The Domestic Worker Convention aims to draw this work out of the shadows and provide these workers with employment rights comparable to other employment occupations while supplementing these with standards that recognise 'the special conditions under which domestic work is carried out' (C189).

However, as much as C189 is to be applauded, and notwithstanding its shortcomings, the uncertainty that there will be any significant take-up by member states, as well as the general inability to enforce the provisions of the instrument does not imbue much confidence that $\mathrm{C} 189$ will deliver any substantial improvements in employment protections and rights for domestic workers. This may explain why Sri Lanka and Indonesia have responded to persistent reports of abuses and to criticisms that they are not doing enough to protect workers by announcing changes to labour-export programs with a view to reducing or ending the migration of women for domestic work (Hangzo and Cook 2012; Rosewarne 2012; Wibisono 2012). ${ }^{24}$

The challenge is not simply one that exists because of institutional weaknesses. It also follows from the limitations that then present in the efforts to promote a set of standards designed to deliver 'decent work' for migrant domestic workers. The problem has another source in the structural inequities that define the global political economy. The solutions which the governments of the global South in Southeast Asia and South Asia, with the encouragement of several international organisations, are pursuing in order to address their economic malaise - promoting labour migration to generate remittances, rectify external imbalances and boost capital stocks - simply transfer the economic and social pressures to another arena. Reorienting domestic labour resources to promote participation in the global labour market as a means of addressing domestic economic crises simply displaces the crises, and the structural inequities become embedded in the market, in the failure of the global labour market to provide 'decent work'. The promised benefits from developing labour-export programs on the basis of the supposed comparative advantage in low-skilled women's labour are undermined by the intensifying competition as more countries are drawn to this strategy and as economic and personal circumstances drive women into pursuing employment through irregular channels, on the one hand, and the exercise of national sovereignty and reluctance of host nation states to deliver 'decent work' for temporary migrant workers.

The Convention does provide a number of in-principle foundations on which to pursue the employment rights of migrant domestic workers, most notably in its antidiscrimination provisions that advocate comparable rights to the citizens and permanent residents of the host nation. Some critics have argued that there are a number of measures that would not be too controversial which could be adopted to extend the rights of migrant workers, such as regularising the employment of workers through circular migration (Vertovec 2007). Another proposal is to make certain worker entitlements internationally portable, such as could be done with employment-related social security contributions, pension and/or health benefits (Piper 2007). However, these measures suffer from some of the shortcomings identified with C189. While they would go some 
way to promoting migrant domestic workers' human rights, they do not address a number of key hallmarks of human rights, and particularly those associated with permanent residence such as family and political rights. The regularisation of residence and employment status, as has occurred in some European Union member-state countries, is one of the very few ways in which the shortcomings can be addressed.

Any substantive legal and material strengthening of migrant domestic worker rights is obviously going to have to rely on the force and effectiveness of the political pressure brought to bear by advocacy groups, migrant worker organisations and civil society organisations, in conjunction with the organised labour movement, and this in turn will be shaped by the strength of transnational and international lobbying and campaigning. But this struggle will still have to confront an international organisational architecture that, when it comes to labour rights, privileges the sovereign authority of the nation-state. Even then the movement will have to tackle the structural inequities across the global economy that prompt governments to promote labour-export policies and the economic conditions that drive women to migrate, through regular and regulated channels as well as clandestinely. This will necessitate challenging the market forces which inject the competitive urge to contain the cost of employing foreign domestic workers, retard the terms and conditions, and act to systemically fetter efforts to redress the labour market disadvantage of the global woman worker. The effectiveness of the campaign for decent work for domestic workers will be contingent upon reining in the competitive imperatives that frame the global labour market and on countering the institutional restrictions on foreign domestic workers that circumscribe their ability to exercise all of their industrial and human rights in the employing nations, and, by and large, these cannot be readily pursued through the auspices and machinery of the ILO.

\section{ACKNOWLEDGEMENT}

The author would like to thank the anonymous referees of this paper for their valuable feedback.

\section{NOTES}

1. The Domestic Worker Convention includes in its cross-referencing, for instance, the Migration for Employment Convention (C 97), the Migrant Workers (Supplementary Provisions) Convention (C143), Workers with Family Responsibilities Convention (C 156), the International Convention of the Elimination of All Forms of Discrimination Against Women, the International Convention of the Elimination of All Forms of Racial Discrimination, and International Convention on the Protection of the Rights of All Migrant Workers and Their Families. 
2. One notable exception was Britain's Transport and General Workers' Union which supported the Filipino migrant worker groups (Schwenken 2005).

3. Filipino migrant worker organisations, such as the Commission for Filipino Migrant Workers (CFMW), BABAYLAN Philippine Women's Network in Europe, and 'Rights, Equality, Solidarity, Power, Europe, Co-operation, Today (RESPECT), have been the most dynamic, partly reflective of the more robust civil society and partly because many activists were political refugees having fled the Marcos regime. Women from some Eastern European countries were reluctant to join such movements because they did not want to be identified with low-status work.

4. For example, the Singaporean government proscribes any foreign involvement in civil society, which has resulted in some local efforts to provide support for Filipina migrant workers drawing on informal networks based in the Philippines.

5. The list of publications in the field is voluminous.

6. This was made quite clear when I was conducting my field research, which was very ably facilitated by interviewees who were only too helpful in introducing me to peers.

7. UNIFEM has or is conducting empowerment programs throughout much of Southeast and South Asia and in some Middle Eastern states.

8. The International Union of Food, Agricultural, Hotel, Restaurant, Catering, Tobacco and Allied Workers.

9. Interestingly, in order to placate criticisms that not enough was being done to protect Cambodian women from being abused, the Malaysian National Association of Employment Agencies (Pikap) joined the Association of Cambodian Recruitment Agencies in offering to set up shelters for domestic workers who want to escape mistreatment at the hands of their Malaysian employers (Aruna 2011).

10. Indonesia had banned foreign domestic worker migration to Malaysia following reports of a series of abuses. The ban was lifted after Indonesia finalised a bilateral Memorandum of Understanding with Malaysia, and Cambodia is presently negotiating a similar agreement in similar circumstances (Aruna 2011; Nie 2012). Indonesia drew up a list of Singaporean agencies that were banned from negotiating the recruitment of workers with their Indonesian counterparts (Tan 2012).

11. In fact, the failure of these particular governments to effectively implement labour migration restrictions forced them to lift restrictions on the migration of women workers.

12. The Malaysian government, for example, advised employers that it had every confidence that the Indonesian government's decision to ban the issue of exit visas for 
workers seeking employment in Malaysia would have little impact on the flow of workers.

13. Indonesia, for example, has threatened to re-impose the ban on the flow of domestic workers to Malaysia following reports of further abuses (Nie 2012). It is also widely acknowledged that MOUs do not offer as much protection as they promise because 'contract substitution' is a common practice, and one criticism of the Domestic Workers Convention is that this is not explicitly proscribed (CARAM 2011; UFDWRs 2011).

14. Qatar has signalled its intention of dropping the sponsorship system and adopting a contract recruitment system (Asian Tribune, 6 May 2012).

15. The governments of labour-export economies are also moved to seek out new sources of labour as migrant workers explore more rewarding destinations for work (Looi, S. Goha, L and Raman, A. 2009; Nee 2011).

16. Bangladeshi women were the lowest paid domestic workers.

17. The non-ILO members included representatives from Human Rights Watch, Migrant Forum in Asia, International Christian Young Workers and Defence for Children International. The IUF representative was a domestic worker.

18. The principle mechanisms intended to draw domestic workers into the mainstream include for those member states that ratify the Convention: the right to freedom of association and collective bargaining; the specification of the terms and conditions of employment, and that these be set out in the job offer or contract of employment; entitlement to fair terms of employment as well as decent working conditions; access to industrial courts or tribunals or other dispute resolution procedures, and; protection from abusive practices and freedom from discrimination in respect of employment and occupation. Some employment concerns more specific to migrant workers are also addressed, including the requirement that contracts of employment be provided prior to crossing borders, the right to retain their travel and identity documents, protection from abuse by recruitment agencies, and implores members to 'cooperate with each other to ensure effective protection of migrant domestic workers' (Articles 7, 9 and 16).

19. Cyprus, Italy and Spain, the most significant European employment locations for Filipina and Sri Lankan domestic workers, have ratified C97, and only Cyprus and Italy have ratified $\mathrm{C} 143$. These are among the minority of EU member states that have ratified the Migration for Employment Convention and only four the Migrant Workers (Supplementary Provisions) Convention. Neither Canada nor the USA have ratified the Conventions.

20. In countries that issue temporary employment permits for foreign domestic workers, the evidence points to a quite well defined hierarchy of remuneration and conditions of employment that varies according to race and ethnicity, nationality and religion. 
21. The much celebrated case was brought by Ms Evangeline Banao Vallejos, who had worked in Hong Kong since 1986, and contended that she was eligible to apply for permanent residence. Vallejos appealed a previous determination that she was not eligible to apply for permanent residence or a Hong Kong Permanent Identity Card. The judicial review has found in her favour. The ruling by the First Court of Instance was not the first instance of a determination granting resident rights to a foreign domestic worker, although it is the first to grant permanent residence. Hong Kong's First Court of Instance's Justice Johnson Lam, who heard Ms Vallejos's appeal, had previously granted 'unconditional stay' to the Filipino Daniel Domingo, who have lived in Hong Kong since the 1980s, and Irene Raboy Domingo and their three children who were born in Hong Kong. The Hong Kong Federation of Trade Unions, which historically has been a strong advocate of foreign domestic worker rights, criticised the FCI ruling arguing that awarding permanent residence rights to low-status migrant workers could have deleterious labour market implications for the broader work force (Hunt 2012).

22. Hong Kong's the Immigration Ordinance expressly excludes foreign domestic workers from applying for permanent residence rights. Following Hong Kong's handover to China, the administration amended the Hong Kong Immigration Ordinance to explicitly exclude four classes of persons from the definition of ordinary resident: foreign contract workers under labour importation schemes, 'foreign domestic helpers', consular staff in Hong Kong, and members of the People’s Liberation Army Garrison.

23. These include: Belgium, Brazil, Colombia, Indonesia, Kenya, Mauritius, Namibia, Norway, Peru, Philippines, South Africa, and Uruguay. However, many of the countries that did support the resolution of $\mathrm{C} 189$ are unlikely to ratify it.

24. The announcement by Indonesia's Manpower Transmigration Minister, Muhaimin Iskander, that in the face of continuing reports of abuse, Indonesia has developed the Domestic Worker Roadmap 2017 to end migration followed action brought by domestic workers' rights activists (by the Action Committee on Domestic Workers, an umbrella group representing 162 activist organisations and individuals) against the government for failing to protect the country's 'maids' (sic) at home and abroad - and failing to ratify the conventions on migrant workers - was dismissed in the Central Jakarta District Court (Triyano 2012).

\section{REFERENCES}

Afsar, R. (2005) 'Conditional Mobility: The Migration of Bangladeshi Female Domestic Workers' in H. Shirlena, B.S.A. Yeoh and N. A. Rahman (eds) Asian Women as Transnational Domestic Workers (page nos?). Singapore: Marshall Cavendish. 
Alston, P. (2004) "“Core Labour Standards" and the Transformation of the International Labour Rights Regime', European Journal of International Law 15 (3): 457-521.

Anon (2011) 'Saudi Bans Domestic Workers from Indonesia, Philippines', The Jakarta Globe 30 June. Available at: http://www.thejakartaglobe.com/home/saudi-bansdomestic-workers-from-indonesia-philippines. (Accessed 16 February 2012).

Asia Pacific Mission for Migrants (2011) 'On the Right of Abode for FDWs in Hong Kong: Social Exclusion is the Central Issue’, 10 August.

Bell, D. and Piper, N. (2005) 'Justice for Migrant Workers? The Case of Foreign Domestic Workers in Hong Kong and Singapore,' in W. Kymlicka and H. Baogang (eds), Multiculturalism in Asia (pp. 196-223). Oxford: Oxford University Press.

cawinfo (2012) 'Saudi Warns It Could End Nepal Maids in Country', 30 January. Available at: http://cawinfor.org/2012/01/saudi-warns-it-could-end-nepal-maidsin-country/. (Accessed 17 February 2012).

Coordination of Action Research on AIDS and Mobility (CARAM) (2011) Reality Check! Rights and Legislation for Migrant Domestic Workers Across Asia, Kuala Lumpur, Malaysia. Available at: http://www.caramasia.org/reports/FDWlegislationAsia.pdf. (Accessed 14 February 2012).

Corpez, N. (2011) '90\% of OFWs in Syria Undocumented', ABS-CBN News.com, 2 September. Available at: http://www.abs-cbnnews.com/globalfilipino/09/02/11/90-ofws-syria-undocumented. (Accessed 15 February 2012).

De Regt, M. (2010) “'Ways to Come, Ways to Leave”. Gender, Mobility, and Il/legality Among Ethiopian Domestic Workers in Yemen', Gender and Society 24(2): 237260.

Hangzo, P. and Cook, A. (2012) 'The Domestic Workers Convention 2011: Implications for Migrant Domestic Workers in Southeast Asia', Insight, Centre for Non-Traditional Security Studies. Available at: http://www.rsis.edu.sg/nts/HTML-Newsletter/Insight/NTS-Insight.apr1201.html. (Accessed 30 May 2012).

Hunt, K. (2012) 'Asia Debates More Rights for Domestic Workers', BBC News 20 February. Available at: http://www.bbc.co.uk/news/business-17093311. (Accessed 21 February 2012).

International Labour Conference (2010) Decent Work for Domestic Workers, Fourth Item on the Agenda, Provisional Record $98^{\text {th }}$ Session, Geneva. 
International Labour Conference (2011a) Decent Work for Domestic Workers, International Labour Conference, $100^{\text {th }}$ Session, Report IV(1), Geneva.

International Labour Conference (2011b) Decent Work for Domestic Workers, International Labour Conference, $100^{\text {th }}$ Session, Rapport IV(2B), Geneva.

International Labour Conference (2011c) Decent work for domestic workers - Report of the Committee on Domestic Workers, $100^{\text {th }}$ Session, June, Geneva.

International Labour Organization (2010a) International Labour Migration: A Rightsbased Approach. Geneva: ILO.

Khan, A. and Harroff-Tavel, H. (2011) 'Reforming the Kafala: Challenges and Opportunities in Moving Forward', Asian \& Pacific Migration Journal 20(3-4): 293-313.

Klep, M. (2011) 'Nepal's Economy Dependent on Exploitation', 22 November, United for Foreign Domestic Workers Rights. Available at: http://ufdwrs.blogspot.com.au/2011/11/nepalese-migrant-domesticworkers.html. (Accessed 15 February 2012).

Loh, D. (2011) 'Malaysia Job Prospects Shrink', One Voice for the Voiceless, 15 March. Available at: http://onevoiceforthevoiceless.wordspress.com/2011/03. (Accessed 15 February 2012).

Lok-Sin, L. (2011) 'Protesters Urge Better Protection for Migrant Workers', Taipei Times, 12 December. Available at: http://www.taipeitimes.com/News/front/archives/2011/12/12/2003520533. (Accessed 10 January 2012).

Looi, S., Goha, L. and Raman, A. (2009) 'Most Malaysians Hiring Maids Illegally', The Star Online, 25 February. Available at: http://thestar.com.my/news/story.asp?file=/2009/2/25/nation/20090225092736 \&sec=nation. (Accessed 22 February 2012).

Migrant Forum in Asia. (Center for Migrant Advocacy, Philippines; Center for Education and Communication, India; Refugee and Migratory Movements Research Unit, Bangladesh) (2010) Women Migrant Workers in the UAE: Not Quite in the Portrait. Available at http://www2.ohchr.org/english/bodies/.../MigrantForumAsia_UAE_45.pdf. (Accessed 15 February 2012). 
Migrant Rights International (2012) 'Saudi Demands Reduction of Migrant Worker Recruitment Cost - But Not Out of Compassion', 12 February. Available at: http://www.migrantrights.org/2012/02/12/saudi-demands-reduction-of-migrantworker-recruitment-cost-but-not-out-of-compassion. (Accessed 15 March 2012).

Moors, A. and de Regt, M. (2008) 'Migrant Domestic Workers in the Middle East', in M. Schrover, J. van der Leun, L. Lucassen and C. Quispel (eds), Illegal Migration and Gender in a Global and Historical Perspective (pp. 151-170). Amsterdam: Amsterdam University Press.

Nee, S. (2011) 'Foreign Maids Snubbing Singapore', The Star Online, 8 October. Available at: http://thestar.com.my/news/story.asp?file=/2011/10/8/focus $/ 9650850 \&$ sec $=$ focus (Accessed 16 February 2012).

Nie. Y. (2012) 'Time to Reform Malaysia's Labour Laws for Foreign Domestic Workers', Asian Correspondent, 6 March. Available at: http://asiancorrespondent.com/77479/time-to-reform-malaysias-labour-laws-forforeign-domestic-workers/. (Accessed 22 February 2012).

Piper, N. (2007) 'Political Participation and Empowerment of Foreign Workers - Gendered Advocacy Migrant Labour Organising in Southeast Asia and East Asia', in N. Piper (ed), New Perspectives on Gender and Migration Rights, Entitlements and Livelihoods (pp. 249-275). London: Routledge.

Raghuram, P. (2005) 'Global Maid Trade: Indian Domestic Workers in the Global Market', in H. Shirlena, B.S.A. Yeoh and N. A. Rahman (eds), Asian Women as Transnational Domestic Workers (pp. 146-171). Singapore: Marshall Cavendish.

Raijman, R. Schamma-Gesser, S. and Kemp, A. (2003) 'International Migration, Domestic Work and Care Work: Undocumented Latina Migrants in Israel', Gender and Society 17(5): 727-249.

Rajan, S. Varghese, V. and Kumar, M. (2011) Dreaming Mobility and Buying Vulnerability Overseas Recruitment Practices in India. New Delhi: Routledge.

Rosewarne, S. (2012) 'Trading on Gender: The Perversity of Labour Exports as an Economic Development Strategy', Work Organisation, Labour and Globalization 6(1): 81-102.

Ruhs, M. and Martin, P. (2008) 'Numbers vs. Rights: Trade-Offs and Guest Worker Programs', International Migration Review 42(1): 249-65. 
Sarker, S. (2012) 'Nepal Fails to Stop Exodus of Women Workers', One World South Asia, 14 March. Available at: http://ipsnews.net/news.asp?idnews=56806. (Accessed 20 March 2012).

Sihaloho, M. (2012) “'Abuse Still Rife” at Soekarno-Hatta's TA Terminal', The Jakarta Globe, 15 September. Available at: http:/www.thejarkataglobe.com/home/abusestill-rife-at-soekarno-hattas-tki-terminal/544507. (Accessed 16 September 2012).

Sim, A. and Wee, V. (2009) 'Undocumented Indonesian Workers in Macau: The Human Outcome of Colluding Interests', Critical Asian Studies 41(1): 165-188

Smith-Gary, L. (2010) 'Nepal Lifts Ban on Female Domestic Workers in Gulf State', 9 December. Available at: http://www/care2/com/causes/nepal-lifts-ban-ondomestic-workers-in-gulf-states.html. (Accessed 10 February 2012).

SOLIDAR (2012) 'Roundtable: Protecting the Rights of Domestic Workers - What is the Role of the EU?', 19 October. Available at: http://www.solidar.org/SOLIDAR-Roundtable-Protecting-The.html. (Accessed 1 November 2012).

Standing, G. (2008) 'The ILO: An Agency for Globalization?', Development and Change 39(3): 355-384.

Tan, A. (2012) 'Indonesian Embassy Blacklists 13 Maid Agencies in Singapore', The $\begin{array}{llll}\text { Jakarta } & \text { Globe, } & 10 & \text { August. }\end{array}$ http://www.thejakartapost.com/news/2012/08/10/indonesian-embassy-blacklists13-maid-agencies-spore.html. (Accessed 12 October 2012).

Taylor, M. (2011) 'Race you to the Bottom ... and Back Again? The Uneven Development of Labour Codes of Conduct', New Political Economy 16(4): 445462.

Triyano, A. (2012) 'Court Dismisses Lawsuit Against Indonesian Govt for Failing to Protect Migrant Workers', Jakarta Globe, 7 February. Available at: http://www.thejakartaglobe.com/home/migrant-worker-lawsuit-of-govtdismissed/496475. (Accessed 20 February 2012).

Vertovec, S. (2007) 'Circular Migration: The Way Forward in Global Policy?', International Migration Institute Working Papers 4, University of Oxford.

Wibisono, B. (2012) 'RI to Stop Sending Domestic Helpers in 2017', Antara News, 19 March. Available at: http://www.antaranews.com/en/news/80696/ri-to-stopsending-domestic-helpers-in-2017. (Accessed 1 May 2012). 
Young, B. (2000) 'The "Mistress" and the "Maid" in the Globalized Economy', in L. Panitch and S. Leys (eds), Socialist Register 2001 Working Classes, Global Realities (page nos?). London: Merlin Press.

\section{BIOGRAPHICAL NOTE}

STUART ROSEWARNE is Senior Lecturer in the Department of Political Economy. His research, which is rooted in Marxist and feminist political economy, focuses on issues in International Political Economy. His publications have analysed migrant women workers and international labour market formation, the emergence of a transnational labour force in global construction and union organization. Other research has focused on socialist ecology, the contradictions of energy-intensive capital accumulation and the climate change. Stuart is also an active member of the National Tertiary Education Union. [e-mail: stuart.rosewarne@sydney.edu.au] 